\title{
The long and winding road leading to the successful introgression of downy mildew resistance into onion
}

\author{
O. E. Scholten · A. W. van Heusden · L. I. Khrustaleva · K. Burger-Meijer · \\ R. A. Mank · R. G. C. Antonise · J. L. Harrewijn · W. Van haecke • \\ E. H. Oost $\cdot$ R. J. Peters $\cdot$ C. Kik
}

Received: 7 November 2006/ Accepted: 5 February 2007/Published online: 14 March 2007

(C) Springer Science+Business Media B.V. 2007

\begin{abstract}
Downy mildew resistance originating from Allium roylei Stearn provides a complete resistance to onions and is based on one, dominant gene. Since $A$. roylei can successfully be hybridized with onion ( $A$. серa L.), a breeding scheme aimed at the introgression of this gene
\end{abstract}

O. E. Scholten $(\bowtie) \cdot$ A. W. van Heusden .

L. I. Khrustaleva · K. Burger-Meijer .

C. Kik

Plant Research International (PRI), Wageningen

University and Research Centre, P.O. Box 16, 6700

AA Wageningen, The Netherlands

e-mail: olga.scholten@wur.nl

\section{I. Khrustaleva}

Russian State Agricultural University-Moscow Agricultural Academy named by K.A.Timiryazev, Timiryazev Street 49, 127550 Moscow, Russia

R. A. Mank - R. G. C. Antonise

Keygene NV, P.O. Box 216, 6700 AE Wageningen, The Netherlands

J. L. Harrewijn · W. Van haecke · E.

H. Oost

Nickerson-Zwaan BV, P.O. Box 4, 1749 ZG

Warmenhuizen, The Netherlands

\section{R. J. Peters}

Hazera Genetics Ltd. Mivhor Farm, D.N. Lachish

Darom 79354, Israel

C. Kik

Centre for Genetic Resources (CGN), Wageningen University and Research Centre, P.O. Box 16, 6700

AA Wageningen, The Netherlands was initiated ca. 20 years ago. Several setbacks in this programme were encountered, firstly the identified molecular marker linked to the downy mildew resistance locus became increasingly difficult to use and finally lost its discriminating power and secondly the final step, making homozygous introgression lines (ILs), turned out to be more difficult then was hoped. GISH analysis showed that the chromosomal region harbouring the resistance locus was the only remaining piece of $A$. roylei in the nuclear background of onion and it also confirmed that this region was located on the distal end of chromosome 3. It was hypothesized that some factor present in the remaining $A$. roylei region was lethal when homozygously present in an onion genetic background. The identification of an individual with a smaller and more distally located introgression fragment and homozygous ILs in its progeny validated this hypothesis. With the help of these nearly isogenic lines four $\mathrm{AFLP}^{\circledR}$ markers closely linked to the resistance gene were identified, which can be used for marker-aided selection. The introduction of downy mildew resistance caused by Peronospora destructor into onion is a significant step forward in the development of environmentally-friendly onion cultivars.

Keywords Allium cepa $\cdot$ A. roylei $\cdot$ Downy mildew · GISH · Marker assisted breeding . Lethal factor 


\section{Introduction}

Downy mildew, caused by the oomycete Peronospora destructor (Berk.) Casp is a fungal disease occurring worldwide, that causes substantial damage when relatively cool moist weather prevails. Downy mildew seldom destroys onion plants completely, but bulb growth is reduced. The disease is one of the most destructive in onion seed production world-wide and is the biggest threat in Dutch onion cultivations. To control downy mildew farmers apply fungicides ca. seven times during the growing season, with possible unwanted side effects like environmental pollution and threats to human health. Integrated pest management and disease forecasting systems like 'Downcast' (Hildebrandt and Sutton 1984; De Visser 1998) are used to reduce the amount of fungicides sprayed. However, when no fungicides are used to control the disease, as is the case in organic agriculture, or when governmental rules forbid the use of certain fungicides, downy mildew infestation can be disastrous. For example by law farmers in the Netherlands have to harvest their onions immediately when more then 8,000 infected leaves are observed within an area of $100 \mathrm{~m}^{2}$ (Meijer and Ten Berge 2004), causing significant yield losses. The best way therefore to deal with downy mildew is to prevent the spread of the disease by the use of downy mildew resistant onion cultivars.

Since 1970 cultivars of onion, Allium cepa L., and related Allium species were screened, aiming at the identification of sources of resistance to downy mildew (Kofoet and Zinkernagel 1990). Until the mid eighties only one source of resistance (cv. Calred; Jones and Mann 1963) was found that gave resistance in the flowering stalks but not in the leaves. In the late eighties the species A. roylei Stearn was found to be completely resistant to downy mildew (Van der Meer and De Vries 1990). This observation was verified by Kofoet and Zinkernagel using a higly reproducible test under greenhouse conditions (Kofoet et al. 1990; Kofoet and Zinkernagel 1990). Although Havey (1992) showed that the cpDNA of $A$. roylei was closely related to section Cepa, both species were taxonomically assigned to different sections by a number of authors (see
Gregory et al. 1998). Van Raamsdonk et al. (2000, 2003) compared DNA of A. roylei with other Allium species and concluded that its nuclear DNA is related to species from the section Cepa and its cpDNA to species from the sections Cepa and Schoenoprasum indicating that A. roylei possibly has a hybrid origin (sensu Hanelt 1990). Successful hybridization between $A$. roylei and $A$. cepa resulted in interspecific hybrid plants that proved to be partially fertile, giving possibilities to exploit the genetic variation present in $A$. roylei for the breeding of new onion cultivars (Van der Meer and De Vries 1990). As the interspecific hybrid was completely resistant to downy mildew and its backcross progeny with onion segregated in a 1:1 ratio, Kofoet et al. (1990) concluded that resistance to downy mildew in $A$. roylei could be explained by the presence of a single dominant locus which was named $P d 1$. Later progenies, obtained by selfing these interspecific hybrid plants, were analyzed, and it became less clear that the inheritance of resistance to downy mildew was based on one dominant gene only, as the observed segregation ratios significantly deviated from the expected $3: 1$ ratio (De Vries et al. 1992a).

To assist the introgression of resistance to downy mildew from $A$. roylei into $A$. серa, random amplified polymorphic DNA (RAPD) markers were screened via a bulked segregant analysis approach (BSA, Michelmore et al. 1991). Three linked roylei-specific markers were identified and the closest one was ca. $2.6 \mathrm{cM}$ from the Pd1 locus (De Vries et al. 1992b). This result strongly supported the one-locus hypothesis. The RAPD marker was converted into a SCAR marker and mapped on the molecular linkage map based on the $A$. серa $\times A$. roylei cross at the distal end of chromosome 3 (Van Heusden et al. 2000a, 2000b). Van Heusden et al. (2000a) also showed that the percentage of roylei alleles in the $\mathrm{F}_{2}$ population was on average $56 \%$ but varied among individual $\mathrm{F} 2$ plants from $32 \%$ to $85 \%$. This skewed distribution may explain the original confusion about the number of involved genes.

In the present paper, the successful introgression of the downy mildew resistance gene in cultivated onion is described in spite of several, previously mentioned, unexpected setbacks. 
Introgression of a single dominant resistance gene is seen as a straightforward procedure in breeding. However, obtaining homozygous resistant plants turned out to be complicated. With the application of GISH and AFLP ${ }^{\circledR}$ markers this situation could be clarified.

$\mathrm{AFLP}^{\circledR}$ is a registered trademark and the AFLP $^{\circledR}$ technology is covered by patents and patent applications of Keygene N.V.

\section{Materials and methods}

\section{Plant material}

Allium roylei Stearn accession PI243009 was used as the pollen parent in a hand cross with $A$. cepa cv. 'Jumbo' to produce an interspecific $\mathrm{F}_{1}$ hybrid. One hybrid plant was backcrossed with $A$. cepa cv. 'Hylight' to produce a $\mathrm{F}_{1} \mathrm{BC}_{1}$ population. This $\mathrm{F}_{1} \mathrm{BC}_{1}$ was backcrossed with onion cultivar 'Maxima' to produce a $\mathrm{F}_{1} \mathrm{BC}_{2}$ population. Seed of this $\mathrm{BC}_{2}$ population was released to various breeding companies, and in addition a SCAR marker closely linked to the downy mildew resistance locus was made available. Released material has been backcrossed three times using different onion cultivars to produce $\mathrm{F}_{1} \mathrm{BC}_{5}$ populations, followed by two or three generations of selfing to obtain several $\mathrm{F}_{1} \mathrm{BC}_{5} \mathrm{~S}_{2}$ and $\mathrm{F}_{1} \mathrm{BC}_{5} \mathrm{~S}_{3}$ populations. During the process of backcrossing and inbreeding, resistant plants were selected in the field and before seed production as described below.

\section{Production of downy mildew inoculum}

Onion leaves with downy mildew symptoms were collected and, if needed, stored at $-20^{\circ} \mathrm{C}$. Spores were suspended in distilled water and filtered through two layers of cheese cloth. Spore suspensions with concentrations of $5.0 \times 10^{4}$ spores $\mathrm{ml}^{-1}$ and a droplet of Tween-20 were injected into onion bulbs. Wounds were covered with parafilm. Bulbs were stored at $10{ }^{\circ} \mathrm{C}$ in a closed plastic bag containing humid paper. After $24 \mathrm{~h}$, temperature was increased to $15{ }^{\circ} \mathrm{C}$ to stimulate mycelium growth. After seven days, inoculated bulbs were planted in pots to obtain eventually sporulating plants. Injected onion bulbs can also be used for the controlled overwintering of the fungus as it has an obligate biotrophic nature.

Instead of bulbs, plants were also used for inoculation. Leaves were cut to $15 \mathrm{~cm}$ and sprayed with the aforementioned spore suspension Plants were placed in a growth chamber at $10{ }^{\circ} \mathrm{C}$ and $100 \% \mathrm{RH}$. After $24 \mathrm{~h}$, plants were transferred to the greenhouse and kept at a temperature of $17^{\circ} / 15^{\circ} \mathrm{C}$ day/night. To induce sporulation on the leaves, plants were moistened by spraying them with distilled water and Tween20 and kept at $100 \% \mathrm{RH}$ and $15^{\circ} \mathrm{C}$ for $24 \mathrm{~h}$ (Kofoet et al. 1990).

\section{Downy mildew field tests}

Inoculated bulbs were planted on the trial field two weeks after seed germination. In addition non-inoculated bulbs of the same or another susceptible variety were planted to serve as spreader plants to obtain sufficient disease pressure in the field. At the end of the season, a second round of inoculation was performed on harvested bulbs to prevent the selection of susceptible plants that escaped infection in field. All resistant looking bulbs were directly inoculated with a downy mildew spore suspension and planted in the greenhouse. Plants were then kept under plastic cover, in order to create a $100 \% \mathrm{RH}$ to induce sporulation. After a period of two-three weeks resistant plants were selected.

\section{Genomic in situ hybridization (GISH)}

Young root tips of plants from $\mathrm{F}_{1} \mathrm{BC}_{5} \mathrm{I}_{3}$ populations 2348 (14 plants) and 3591 (six plants) were collected for metaphase chromosome spread analysis. Slides with a full set of chromosomes in well spread metaphase $(2 n=2 x=16)$ were selected for GISH experiments. Genomic DNA was extracted from young leaves of onion and $A$. roylei using the CTAB method of Roger and Bendich (1998). Genomic DNA of A roylei was labelled with Dig-11-dUTP by standard nicktranslation (Boehringer, Mannheim, Germany). Genomic DNA of onion was used as block DNA. In situ hybridization, immunological detection and microscopy procedures were as 
previously described by Khrustaleva and Kik (1998, 2000). Karyotype analysis were carried out according to the standard onion nomenclature system as proposed by Kalkman (1994) and confirmed by the Fourth Eucarpia Allium symposium (De Vries 1990). Chromosome measurements from three-five metaphases per genotype were performed with a freeware programme for Windows version 3.3 from Colorado State University (www.colostate.edu/depts/biology/micromeasure).

AFLP $^{\circledR}$ markers

DNA was isolated, using a standard CTAB method, from leaves of randomly selected A. сера Rijnsburger cultivars, A. roylei, and individuals from population 2348 (ten plants) and 3591 (two plants). AFLP analysis was carried out as described by Vos et al. (1995) using the enzyme combination PstI/MseI. A two-step amplification strategy was followed. Starting with a selective pre-amplification in which both AFLP primers had a single selective nucleotide. The second selective amplification step was carried out using primers having three selective nucleotides each. The PstI primer was end-labelled using $[\gamma-33 \mathrm{P}] \mathrm{ATP}$ and T4 polynucleotide kinase. AFLP reactions and following gel analysis were performed according to Vos et al. (1995). Gel images were electronically scanned and all polymorphic AFLP fragments were scored using the proprietary software developed specifically for AFLP analysis at Keygene. This software allows the display and analysis of pixel images of phosphorimager scans (fingerprints). For the analysis of the fingerprints, the software has tools to navigate through the image and individual band signals and to size and quantify the AFLP bands with great precision. Restriction enzymes, adapters, and primers used are listed in Table 1. The following primer combinations (PC) were used: P31M48, P32M62, P33M32, P35M51, P43M35, P45M35. Each polymorphic AFLP fragment was identified by: 1) the code referring to the corresponding PC, followed by 2) the estimated molecular size of the DNA fragment in nucleotides. A $10 \mathrm{bp}$ DNA ladder from SequaMark (Research Genetics, Huntsville, Ala. USA) was
Table 1 Sequences of amplified fragment length polymorphism (AFLP) primers and adapters

\begin{tabular}{|c|c|}
\hline $\begin{array}{l}\text { Primers/ } \\
\text { adapters }\end{array}$ & Sequences \\
\hline MseI adapter & $\begin{array}{l}5^{\prime} \text {-GACGATGAGTCCTGAG-3' } \\
3^{\prime} \text {-TACTCAGGACTC AT-5' }\end{array}$ \\
\hline Pst $\mathrm{I}$ adapter & $\begin{array}{l}\text { 5'-CTCGTAGACTGCGTACATGCA- } \\
3^{\prime} \\
3^{\prime} \text {-TGTACGCAGTCTAC-5' }\end{array}$ \\
\hline \multicolumn{2}{|c|}{ Universal primers } \\
\hline M00 & GATGAGTCCTGAGTAA \\
\hline P00 & GACTGCGTACATGCAG \\
\hline \multicolumn{2}{|c|}{ Pre-amplification } \\
\hline M01 & $\mathrm{M} 00+\mathrm{A}$ \\
\hline M02 & $\mathrm{M} 00+\mathrm{C}$ \\
\hline P01 & $\mathrm{P} 00+\mathrm{A}$ \\
\hline \multicolumn{2}{|l|}{ AFLP-primers } \\
\hline \multicolumn{2}{|c|}{ Mse I +3 primers } \\
\hline M32 & $\mathrm{M} 00+\mathrm{AAC}$ \\
\hline M35 & $\mathrm{M} 00+\mathrm{ACA}$ \\
\hline M51 & $\mathrm{M} 00+\mathrm{CCA}$ \\
\hline M62 & $\mathrm{M} 00+\mathrm{CTT}$ \\
\hline \multicolumn{2}{|c|}{ Pst $\mathrm{I}+3$ primers } \\
\hline P31 & $\mathrm{P} 00+\mathrm{AAA}$ \\
\hline P32 & $\mathrm{P} 00+\mathrm{AAC}$ \\
\hline P33 & $\mathrm{P} 00+\mathrm{AAG}$ \\
\hline P35 & $\mathrm{P} 00+\mathrm{ACA}$ \\
\hline $\mathrm{P} 43 \mathrm{~s}$ & $\mathrm{P} 00+\mathrm{ATA}$ \\
\hline $\mathrm{P} 45$ & $\mathrm{P} 00+\mathrm{ATG}$ \\
\hline
\end{tabular}

used as size standard to estimate the molecular weight of the fragments.

\section{Results}

Use of SCAR marker

The SCAR-marker linked to the downy mildew locus functioned well the first few years and could also be easily mapped in the interspecific mapping population (Van Heusden et al. 2000a). This mapping indicated that the resistance gene was located on the distal end of chromosome 3. However, in the course of time not only the $A$. roylei specific fragment was amplified by the SCAR primer set but also a faint fragment of the same length was obtained in onion cultivars. Therefore the marker lost its discriminating power. Despite considerable efforts it has not been possible to regain a useful, robust marker. 
Segregation for downy mildew resistance in advanced backcross progenies

A total of $41 \mathrm{~F}_{1} \mathrm{BC}_{5}$ progenies were produced in 1995 and 1996 . Twenty of the $21 \mathrm{~F}_{1} \mathrm{BC}_{5}$ progenies from 1995 segregated in resistant and susceptible plants. From all progenies resistant plants were randomly selected and selfed, resulting in a total of $95 \mathrm{~F}_{1} \mathrm{BC}_{5} \mathrm{~S}_{1}$ progenies. From these progenies, again resistant plants were selfed resulting in 144 $\mathrm{F}_{1} \mathrm{BC}_{5} \mathrm{~S}_{2}$ progenies. Contrary to the expectations with one dominantly acting gene (one third of the progenies completely resistant), none of the 144 progenies was completely resistant. Due to this unexpected result again $71 \mathrm{~F}_{1} \mathrm{BC}_{5} \mathrm{~S}_{2}$ downy mildew resistant plants were selected and selfed. Among these progenies, only one progeny was found of which all plants were resistant (progeny 3591).

\section{GISH analysis of two selected progenies}

Fourteen downy mildew resistant plants of $\mathrm{F}_{1} \mathrm{BC}_{5} \mathrm{~S}_{3}$ progeny 2348 , a progeny that segregated for resistance, and six plants from $\mathrm{F}_{1} \mathrm{BC}_{5} \mathrm{~S}_{3}$ progeny 3591, a progeny that consisted of only resistant plants, were investigated using GISH. It was clear that the breeding effort had been very successful as only one chromosomal region of $A$. roylei was still present after five backcross generations in an onion genetic background (Fig. 1). Karyotype analysis showed that the $A$. roylei fragment located on the distal end of the long arm of chromosome 3 (centromeric index -41.7 and the relative chromosome length -13.8). For the 'resistant' $\mathrm{F}_{1} \mathrm{BC}_{5} \mathrm{I}_{3}$ progeny 3591 all six plants possessed $A$. roylei fragments on both homologues. Among these plants, five possessed two $A$. roylei fragments that differed in size and contained a large and a small $A$. roylei fragment (Fig. 1a). One plant, 3591-1, was homozygous for the two small fragments on both homologues of chromosome 3 (Fig. 1b). The size of the large fragment averaged $42.8 \pm 1.09 \%$ of the length of the long arm and the size of the small fragment averaged $17.9 \pm 0.78 \%$. GISH study proved that non-segregated 'resistant' $\mathrm{F}_{1} \mathrm{BC}_{5} \mathrm{I}_{3}$ progeny 3591 were homozygous for the area harbouring the downy mildew resistance locus. GISH analysis on resistant plants from progeny 2348 showed that all fourteen plants were heterozygous for the $A$. roylei fragment (only one homologue chromosome possessed the large A. roylei fragment; Fig. 1c). The size of the fragment was $42.8 \pm 0.89$ $\%$ of the length of the long arm. GISH analysis of two progenies 3591 and 2348 did not reveal any individual plant that possessed two large $A$. roylei fragments on both homologues.

The development of molecular markers linked to downy mildew resistance

GISH analysis illustrated the difference in length of the roylei fragments in the backcross inbred lines. This allowed a fast and efficient search for new molecular markers linked to downy mildew
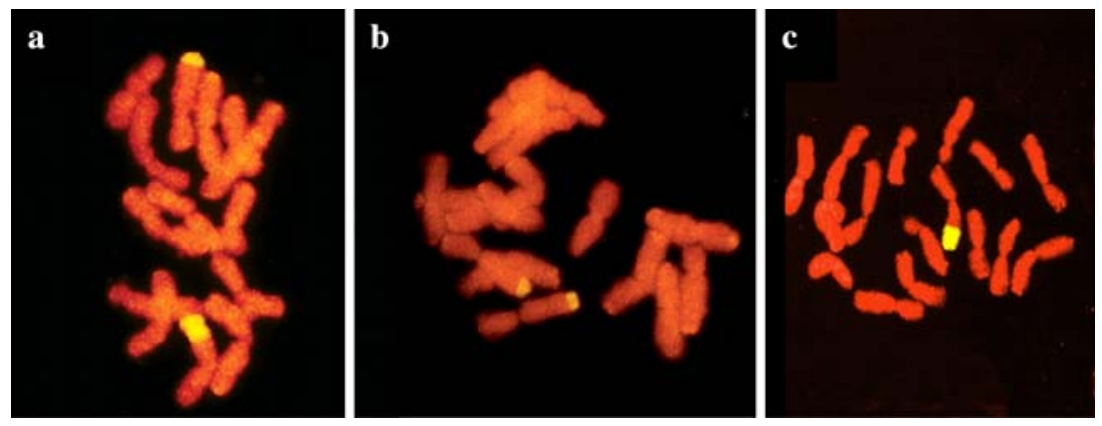

Fig. 1 GISH to metaphase chromosomes of downy mildew resistant plants: from population 3591, (a) plant 3 homozygously resistant with a small and a large introgression fragment and (b) plant 1 homozygously resistant with the small introgression fragments; from population 2348, (c) plant 2 heterozygously resistant with the large introgression fragment 
resistance. Comparison of AFLP-fingerprints of a plant heterozygous for the large A. roylei fragment (Fig. 1c), with a plant that is homozygous for the smaller $A$. roylei fragment (Fig. 1b) with AFLP-fingerprints of $A$. cepa and $A$. roylei, only markers will be identified closely linked to the downy mildew resistance locus.

AFLP analysis was carried out using DNA of three different plants: 2348-6 (heterozygously resistant; large introgression fragment), 3591-1 (homozygously resistant; small introgression fragment) and $A$. roylei (homozygously resistant), in combination with a bulk of four $A$. cepa plants (susceptible). For verification, a second AFLP analysis was carried out to screen a number of the candidate linked markers on the additional plants of progenies 2348 and 3591 as positive controls and 24 additional $A$. cepa individuals as negative controls. In the first analysis a total of 96 primer combinations of the Pst $\mathrm{I}+3 / M s e \mathrm{I}+3$ matrix

Table 2 Presence of AFLP markers linked to the proximal part of the large and to the remaining distal small introgression fragment from $A$. roylei in individual geno- were used. The AFLP analysis resulted in the identification of 34 candidate markers, of which 26 were linked to the proximal part of the large introgression fragment and eight to the distal part (also called the small introgression fragment). Further verification on a selection of these markers resulted in the identification of four markers linked to the large and six markers linked to the small introgression fragment. Two of the markers, linked to the small introgression fragment, were also present in one of the four $A$. сера individuals used for the bulk and in one out of 24 other $A$. cepa genotypes tested. These two markers can therefore not be used as markers for further selection. The markers for the large and small introgression fragments were also present in the additional ' 2348 ' individuals, and the markers linked to the small introgression fragment were present in the ' 3591 ' individuals (Table 2).

types of $\mathrm{F}_{1} \mathrm{BC}_{5} \mathrm{I}_{3}$ progenies 2348 and 3591, the A. roylei parent and four $A$. cepa cultivars

\begin{tabular}{|c|c|c|c|c|c|c|c|c|c|c|}
\hline & \multicolumn{4}{|c|}{$\begin{array}{l}\text { Markers linked to the proximal part of the } \\
\text { large introgression fragment }\end{array}$} & \multicolumn{6}{|c|}{ Markers linked to the remaining small introgression fragment } \\
\hline & $\begin{array}{l}\text { P31/M48- } \\
186\end{array}$ & $\begin{array}{l}\mathrm{P} 32 / \mathrm{M} 62- \\
322\end{array}$ & $\begin{array}{l}\mathrm{P} 32 / \mathrm{M} 62- \\
079\end{array}$ & $\begin{array}{l}\text { P33/M32- } \\
115\end{array}$ & $\begin{array}{l}\text { P33/M32- } \\
155\end{array}$ & $\begin{array}{l}\text { P45/M35- } \\
062\end{array}$ & $\begin{array}{l}\text { P32/M62- } \\
061\end{array}$ & $\begin{array}{l}\mathrm{P} 33 / \mathrm{M} 32- \\
151\end{array}$ & $\begin{array}{l}\text { P35/M51- } \\
330\end{array}$ & $\begin{array}{l}\mathrm{P} 43 / \mathrm{M} 35- \\
190\end{array}$ \\
\hline 2348-1 & $+^{1}$ & + & + & + & + & + & + & + & + & + \\
\hline $2348-3$ & + & + & + & + & + & + & + & + & + & + \\
\hline $2348-6$ & + & + & + & + & + & + & + & + & + & + \\
\hline $2348-7$ & + & + & + & + & + & + & + & + & + & + \\
\hline $2348-8$ & + & + & + & + & + & + & + & + & + & + \\
\hline $2348-13$ & + & + & + & + & + & + & + & + & + & + \\
\hline $2348-14$ & + & + & + & + & + & + & + & 1 & + & + \\
\hline $2348-15$ & + & + & 1 & + & + & + & + & + & + & + \\
\hline $2348-16$ & + & + & + & + & + & + & + & + & + & + \\
\hline $2348-18$ & + & + & + & + & + & + & + & + & + & + \\
\hline $2348-19$ & - & + & + & + & + & 1 & + & - & + & + \\
\hline $3591-1$ & - & - & - & - & + & + & + & + & + & + \\
\hline $3591-3$ & + & + & + & + & + & + & + & + & + & + \\
\hline $\begin{array}{l}A . \\
\quad \text { roylei }\end{array}$ & + & + & + & + & + & + & + & + & + & + \\
\hline $\begin{array}{l}\text { A. cepa } \\
\text { A }\end{array}$ & - & - & - & - & - & - & - & - & - & - \\
\hline $\begin{array}{l}\text { A. сера } \\
\text { B }\end{array}$ & - & - & - & - & - & - & - & - & - & - \\
\hline $\begin{array}{l}\text { A. сера } \\
\text { C }\end{array}$ & - & - & - & - & - & - & - & - & - & - \\
\hline $\begin{array}{l}\text { A. сера } \\
\text { D }\end{array}$ & - & - & - & - & + & + & - & - & - & - \\
\hline
\end{tabular}

The enzyme primer combination and the size of the fragment (bp) are given. $+=$ AFLP fragment present, $-=$ AFLP fragment absent, / = unclear result 


\section{Discussion}

In the course of domestication, the genepool of many agricultural crops became limited, and therefore the possibility of exploiting wild relatives is of high importance in breeding to widen crops' genepools (Cooper et al. 2001). In this context modern tomato and lettuce cultivars have been enriched during the last decades with a large number of traits originating from their crossable wild relatives (Kalloo and Chowdhury 1992). In onion, crossable relatives are scarce and succesful resistance breeding by means of introgression of genes from wild relatives was only started two decades ago with the discovery of $A$. roylei, a species which carried a complete resistance to downy mildew and a high partial resistance to onion leaf blight (for overview see Kik 2002). Later it was also found that $A$. roylei could also serve as a bridging species between onion and bunching onion (A. fistulosum L.), which opened the way for the exploitation of this important gene reservoir for the breeding of new onion cultivars (Khrustaleva and Kik 2000; De Melo 2003). Breeding in onion is a prolonged process, since the crop has a biennial life cycle. In the case of breeding for downy mildew resistance it took around 20 years, from the identification of the downy mildew resistance in $A$. roylei to the release of the first downy mildew resistant cultivars.

The downy mildew resistance locus was shown via GISH to be located on the distal end of chromosome 3 which confirmed the observation of Van Heusden et al. (2000b). Since the SCAR marker lost its discriminative power, probably as a result of aspecific annealing of onion-DNA that became worse in the course of time after development of improved Taq polymerases, AFLP markers were developed for resistance to the downy mildew locus. Homozygosity of the resistance locus is a prerequisite in making completely resistant $\mathrm{F}_{1}$ hybrid seeds. However, the breeding process was complicated by a lethal factor that only seems to be expressed in an $A$. cepa background and which proved to be closely linked to the downy mildew resistance locus. In this context it can be hypothesized that the large introgressed $A$. roylei fragment harbours the recessive lethal factor proximally located to the downy mildew resistant gene. The following observations validated this hypothesis: (i) lack of plants with homozygous for the large A. roylei fragment; (ii) detection of heterozygous plants harbouring a large A. roylei fragment; (iii) the presence of plants homozygous for the smaller distally located $A$. roylei fragment that retained resistance to downy mildew. Therefore the production of a homozygous introgression fragment harbouring the downy mildew resistance proved to be difficult as only one plant homozygous for the small $A$. roylei fragment was found amongst $215(=144+71)$ downy mildew resistant $\mathrm{F}_{1} \mathrm{BC}_{5} \mathrm{~S}_{2}$ plants. By crossing over, the downy mildew resistance locus and the lethal factor were separated and the remaining roylei introgression could be made homozygous without any problems (as explained in Fig. 1). Currently we do not know what the nature is of the lethal factor on the large $A$. roylei fragment in an $A$. cepa genetic background.

The downy mildew case in onion is not a unique case as more examples are known from literature, how difficult it can be to introgress a resistance gene into a cultivated crop. One example is the case of the introgression of an aphid (Nasonovia ribisnigri) resistance into lettuce. The resistance to the aphid was found in Lactuca virosa L. (Eenink and Dieleman 1983). This resistance could only be transferred via a bridge cross to lettuce (L. sativa L.) via L. serriola L. However, the aphid resistance was closely linked to an undesirable plant phenotype and this linkage drag could only be removed with the help of molecular markers and large segregating populations (patent: WO 1997/046080). Another example is the development of introgression line (IL) populations. In the case of tomato, ILs (introgression lines) have been developed from Solanum pennellii LA716 (Eshed and Zamir 1994), S. habrochaites LA1777 Monforte and Tanksley 2000), S. habrochaites LYC4 (Finkers, pers comm), S. habrochaites (Francis et al. 2001) and S. lycopersicoides LA2951 (Canady et al. 2005) and in a number of cases it was difficult or even impossible to make heterozygous ILs homozygous, which also might point to the involvement of lethal factors. 


\section{Conclusion}

After the identification of the downy mildew resistant accession $A$. roylei it took around 20 years to introduce this gene successfully into the cultivated onion and the first resistant cultivars will be introduced on the seed market in the coming one-two years. Work is in progress to introduce this source of resistance, using markerassisted breeding to other onion as well as bunching onion cultivars grown worldwide.

Acknowledgements We like to acknowledge the skilful technical assistance of Jaap van den Berg of Plant Research International in maintaining the plant material and making the first crosses. Joop Hoogenboom and René Douma from the onion-breeding team of NickersonZwaan breeding company are acknowledged for their efforts in breeding for downy mildew resistant onion cultivars and screening of plants materials for resistance.

\section{References}

Canady MA, Meglic V, Chetleat RT (2005) A library of Solanum lycopersicoides introgression lines in cultivated tomato. Genome 48:685-697

Cooper HD, Spillane C, Hodgin T (2001) Broadening the genetic base of crop production. CABI Publ, Wallingford, Oxon, UK

De Melo PE (2003) The root systems of onion and Allium fistulosum in the context of organic farming: a breeding approach. $\mathrm{PhD}$ Thesis, Wageningen University and Research Center, the Netherlands

De Vries JN (1990) Onion chromosome nomenclature and homoeology relationships-workshop report. Euphytica 49:1-3

De Vries JN, Wietsma WA, Jongerius MC (1992a) Linkage of downy mildew resistance genes $P d 1$ and $P d 2$ from Allium roylei Stearn in progeny of its interspecific hybrid with onion ( $A$. cepa L.). Euphytica 64:131-137

De Vries JN, Jongerius R, Sandbrink H, Lindhout $\mathrm{P}$ (1992b) RAPD markers assist in resistance breeding. Prophyta 2:50-51

De Visser CLM (1998) Development of a downy mildew advisory model based on DOWNCAST. Eur J Plant Pathol 104:933-943

Eenink AH, Dieleman FL (1983) Inheritance of resistance to the leaf aphid Nasanovia ribisnigri in the wild lettuce species Lactuca virosa. Euphytica 32:691-695

Eshed Y, Zamir D (1994) A genomic library of Lycopersicon pennellii in L. esculentum: a tool for fine mapping of genes. Euphytica 79:175-179

Francis DM, Kabelka E, Bell J, Franchino B, St-Clair D (2001) Resistance to bacterial canker in tomato
(Lycopersicon hirsutum LA407) and its progeny derived from crosses to L. esculentum. Plant Disease 85:1171-1176

Gregory M, Fritsch RM, Friesen NW, Khassanov FO, McNeal DW (1998). Nomenclator Alliorum. Whitstable Litho Printers Ltd., Whitstable, Kent, UK

Hanelt P (1990) Taxonomy, evolution and history. In: Rabinowitch HD, Brewster JL (eds) Onions and allied crops. CRC Press Inc, Boca Raton, Florida, USA, pp. $1-26$

Havey M (1992) Restriction enzyme analysis of the chloroplast and nuclear 45 s ribosomal DNA of Allium sections Cepa and Phyllodolon. Plant Syst Evol 183:1731

Hildebrandt PD, Sutton JC (1984) Interactive effects of the dark period, humid period, temperature, and light on sporulation of Peronospora destructor. Phytopathol 74:1444-1449

Jones HA, Mann LK (1963) Onions and their Allies. Leonard Hill Ltd, London

Kalkman ER (1994) Analysis of the G-banded karyotype of Allium cepa L. Standard system of nomenclature and polymorphism. Genetica 65:141-148

Kalloo G, Chwodhury JB (1992). Distant hybridization of crop plants. Monographs on Theor and Appl Genet 16, Springer-Verlag Berlin

Khrustaleva LI, Kik C (1998) Cytogenetical studies in the bridge cross Allium cepa $\times($ A. fistulosum $\times$ A. roylei $)$. Theor Appl Genet 96:8-14

Khrustaleva LI, Kik C (2000) Introgression of Allium fistulosum into A. cepa mediated by $A$. roylei. Theor Appl Genet 100:17-26

Kik C (2002) Exploitation of wild relatives for the breeding of cultivated Allium species. In: Rabinowitch HD, Currah L (eds) Allium crop science: recent advances. CABI Publ, Wallingford, UK, pp. 81-100

Kofoet A, Zinkernagel V (1990) Resistance to downy mildew (Peronospora destructor (Berk.) Casp. in Allium species. J Plant Diseases and Protection 97:13-23

Kofoet A, Kik C, Wietsma WA, Vries de JN (1990) Inheritance of resistance to downy mildew (Peronospora destructor (Berk.) Casp.) from Allium roylei Stearn in the backcross Allium cepa L. $\times(A$. roylei $\times$ A. cepa). Plant Breeding 105:144-149

Meijer ThAM, Ten Berge RJM (2004) Verordening HPA bestrijding valse meeldauw bij uien. http:// 193.173.66.231/sf/sf.cgi?1493. Cited 11 Nov 2004

Michelmore RW, Paran I, Kesseli RV (1991) Identification of markers linked to disease-resistance genes by bulked segregant analysis: a rapid method to detect markers in specific genomic regions by using segregating populations. Proc Natl Acad Sci USA 88:9828-9832

Monforte AJ, Tanksley SD (2000) Fine mapping of a quantitative trait locus (QTL) from Lycopersicon hirsutum chromosome 1 affecting fruit characteristics and agronomic traits: breaking linkage among QTLs affecting different traits and dissection of heterosis for yield. Theor Appl Genet 100:471-479 
Rogers SO, Bendich AJ (1998) Extraction of DNA from plant tissues. In: Gelvin SB, Schilperoort RA (eds) Plant Molec Biol manual A6. Kluwer Academic Publ, Dordrecht, the Netherlands, pp. 1-10

Sutton JC, James TDW, Rowell PM (1986) BOTCAST: a forecasting system to time the initial fungicide spray for managing Botrytis leaf blight of onions. Agric Ecosyst Environ 18:123-143

Van der Meer QP, De Vries JN (1990) An interspecific cross between Allium roylei Stearn and Allium cepa L. and its backcross to A. cepa. Euphytica 47:29-31

Van Heusden AW, Van Ooijen JW, Vrielink-van-Ginkel R, Verbeek WHJ, Wietsma WA, Kik C (2000a) A genetic map of an interspecific cross in Allium based on amplified fragment length polymorphism (AFLP ${ }^{\mathrm{TM}}$ ) markers. Theor Appl Genet 100:118-126

Van Heusden AW, Shigyo M, Tashiro Y, Vrielink-vanGinkel R, Kik C (2000b) AFLP linkage group assignment to the chromosomes of Allium cepa L. via monosomic addition lines. Theor Appl Genet 100:480-486

Van Raamsdonk LWD, Vrielink-van-Ginkel M, Kik C (2000) Phylogeny reconstruction and hybrid analysis in Allium subgenus Rhizirideum. Theor Appl Genet 100:1000-1009

Van Raamsdonk LWD, Ensink W, Van Heusden AW, Vrielink-van-Ginkel M, Kik C (2003) Biodiversity assessment based on cpDNA and crossability analysis in selected species of Allium subgenus Rhizirideum. Theor Appl Genet 107:1048-1058

Vos P, Hogers R, Bleeker M, Reijans M, Van de Lee T, Hornes M, Frijters A, Pot J, Peleman J, Kuiper M, Zabeau M (1995) AFLP: a new technique for DNA fingerprinting. Nucleic Acids Res 23:4407-4414 